\title{
Increased serum IgE concentrations during infection and graft versus host disease after bone marrow transplantation
}

\author{
SA WALKER, TR ROGERS, ${ }^{*}$ D PERRY, JR HOBBS, PAMELA G RICHES \\ From the Protein Reference Unit and ${ }^{*}$ Department of Medical Microbiology, Westminster Hospital and \\ Medical School, London SWIP 2AR
}

SUMMARY Serum IgE concentrations estimated in 25 bone marrow transplant recipients during episodes of infection or graft versus host disease, or both, were raised not only in some patients with acute graft versus host disease but also in many patients with infection. Raised values were not seen in chronic graft versus host disease. The routine estimation of serum IgE in bone marrow transplant recipients had minimal value because of the lack of specificity of the IgE response.

Two major causes of morbidity and mortality in bone marrow transplant recipients are infection and acute graft versus host disease, which may be difficult to distinguish clinically and may also occur simultaneously. ${ }^{1}$ There would be obvious value for any laboratory investigation that could be used in the differential diagnosis and monitoring of these complications.

Increased concentrations of serum IgE have been reported after allogeneic bone marrow transplant, ${ }^{2}$ and in some patients the rise accompanied clinical and biochemical evidence of acute graft versus host disease. Later studies ${ }^{3}$ suggested that monitoring serum IgE concentrations might be helpful in reaching an early diagnosis of acute graft versus host disease. The IgE response is $\mathrm{T}$ cell dependent, however, and it is possible that disturbed $T$ cell regulation resulting from infection, particularly viral, might also be associated with raised serum IgE concentrations in the bone marrow, transplant recipients. If this were so, a raised serum IgE would not be a specific and early indicator of acute graft versus host disease.

In the present study serum IgE concentrations were investigated in bone marrow transplant recipients in relation to graft versus host disease and infection.

\section{Patients and methods}

Forty episodes of infection, acute graft versus host

Accepted for publication 2 December 1983 disease, or both, were clearly documented in 25 of 35 bone marrow transplant recipients studied. Patients had been transplanted for acute leukaemia (12), aplastic anaemia (4), or inborn errors of metabolism (9). There were 23 children (age range 11 months-15 years) and two adults (both with acute leukaemia). Serum IgE concentrations were also measured in 16 patients with chronic graft versus host disease, diagnosed clinically and histologically, who had no evidence of infection.

IgE was measured by the Phadebas IgE PRIST method (Pharmacia Diagnostics AB, Uppsala, Sweden).

Serum samples were taken before transplantation and weekly after transplantation until discharge unless infection or graft versus host disease developed, when samples were taken on alternate days. Serum samples were taken from patients with chronic graft versus host disease when they were reviewed as outpatients (range 3 months-4 years after transplantation).

\section{Results}

Serum IgE concentrations were determined during episodes of bacterial, viral, or mixed or other infections, including fungal; in acute graft versus host disease with and without intercurrent infection; and in chronic graft versus host disease. The sites and causative agents of infections occurring in the absence or presence of acute graft versus host disease are shown in Tables 1 and 2 respectively.

In all but three of the bacterial, fungal, and pro- 
Table 1 Infections occurring in the absence of acute graft versus host disease in bone marrow transplant recipients

\begin{tabular}{|c|c|c|}
\hline & Infection & Causative agent \\
\hline Bacterial & $\begin{array}{l}{ }^{*} \text { Pneumonia } \\
\text { *Pneumonia } \\
\text { Pneumonia } \\
\text { Pneumonia and septicaemia } \\
{ }^{*} \text { Septicaemia } \\
\text { Pneumonia and septicaemia } \\
\text { Pyogenic abscess at lumbar puncture site }\end{array}$ & $\begin{array}{l}\text { Streptococcus pneumoniae } \\
\text { Streptococcus pneumoniae } \\
\text { Streptococcus pneumoniae } \\
\text { Streptococcus pneumoniae } \\
\text { Streptococcus faecalis } \\
\text { Streptococcus pneumoniae } \\
\text { Unknown-responded to laminectomy and drainage }\end{array}$ \\
\hline Viral & $\begin{array}{l}{ }^{*} \text { Encephalitis } \\
{ }^{*} \text { Hepatitis } \\
{ }^{*} \text { Hepatitis } \\
{ }^{*} \text { Rash on thigh } \\
{ }^{*} \text { Mucositis }\end{array}$ & $\begin{array}{l}\text { Varicella zoster } \\
\text { Hepatitis B } \\
\text { Non-A non-B hepatitis } \\
\text { Varicella zoster } \\
\text { Herpes simplex }\end{array}$ \\
\hline Fungal/mixed & $\begin{array}{l}{ }^{*} \text { Mucositis } \\
{ }^{*} \text { Enteritis } \\
\text { Mucositis } \\
\text { Vesicles on dorsal trunk } \\
{ }^{*} \text { Brain abscesses } \\
{ }^{*} \text { Cystitis } \\
\text { Pneumonia } \\
\text { Pneumonia } \\
\text { Mucositis }\end{array}$ & $\begin{array}{l}\text { Herpes simplex Candida albicans } \\
\text { Giardia lamblia } \\
\text { Herpes simplex Cand albicans } \\
\text { Staphylococcus aureus Herpes simplex } \\
\text { Cand albicans } \\
\text { Escherichia coli } \\
\text { Unknown-responded to intravenous amphotericin } \\
\text { Mixed coliforms } \\
\text { Herpes simplex Cand albicans }\end{array}$ \\
\hline
\end{tabular}

${ }^{*}$ Increased $\mathrm{IgE}$ concentration at the time of infection.

tozoal infections the diagnosis was confirmed by culture and the patients responded to appropriate treatment. Viral infection was diagnosed by electron microscopy, viral isolation, or rising viral antibody titres. In the few patients in whom a causative agent was not identified there was strong clinical indication of infection or response to treatment or both.

Serum IgE concentrations for all patient groups are shown in the Figure. The incremental rise in IgE was derived by subtracting the value before transplantation from the maximum value observed during an episode. Most of the patients were children with pretransplantation values below $5 \mathrm{IU} / \mathrm{ml}$. In all episodes monitored the IgE concentrations returned

Table 2 Infections occurring in the presence of acute graft versus host disease in bone marrow transplant recipients

\begin{tabular}{ll}
\hline Infection & Causative agent \\
\hline${ }^{*}$ Septicaemia & Streptococcus faecalis \\
Septicaemia & Streptococcus viridans \\
Pneumonia and septicaemia & Proteus mirabilis \\
${ }^{*}$ Septicaemia & Pseudomonas aeruginosa \\
${ }^{*}$ Conjunctivitis & Adenovirus \\
Pneumonia & Parainfluenzavirus \\
${ }^{*}$ Mucositis & Herpes simplex \\
Intestinal candidiasis & Cand albicans \\
${ }^{*}$ Vesicles on dorsal trunk & Staph aureus Herpes simplex \\
${ }^{*}$ Hickman catheter infection & Unknown-improved when \\
& Hickman catheter was removed \\
Pharyngitis & Adenovirus \\
${ }^{*}$ Mucositis & Herpes simplex \\
Candidaemia & Cand albicans \\
Pharyngitis & Cand albicans \\
${ }^{*}$ Pharyngitis & Herpes simplex \\
Pneumonia & Cytomegalovirus \\
Enteritis & Adenovirus \\
\hline
\end{tabular}

*Increased IgE concentration at the time of infection. to baseline values at or soon after clinical improvement.

A rise of serum IgE concentration was associated with $3 / 7$ bacterial infections, $5 / 5$ viral infections, $4 / 6$ mixed or other infections, $8 / 11$ episodes of acute graft versus host disease with infection, and 6/11 episodes of acute graft versus host disease alone, but was invariably absent in chronic graft versus host disease.

\section{Discussion}

This study has confirmed previous reports of raised

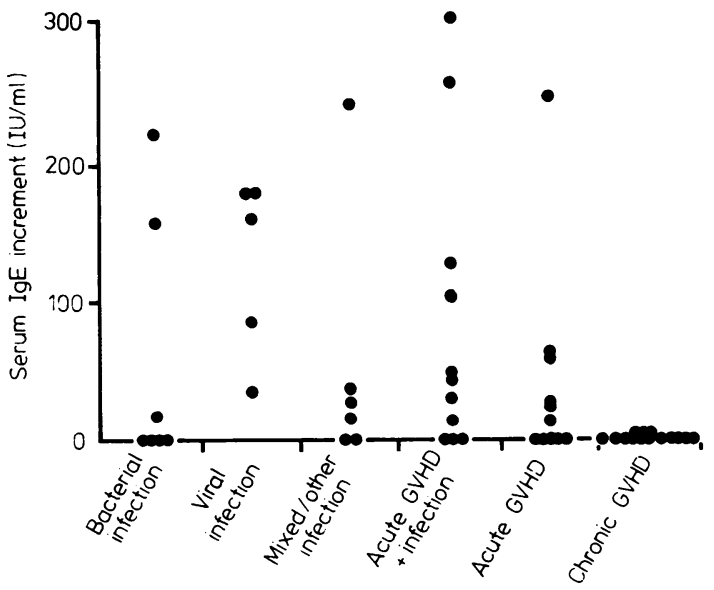

Serum IgE increment in infection and in acute and chronic graft versus host disease (GVHD) in bone marrow transplant recipients. 
serum IgE concentrations in acute graft versus host disease and unchanged values in chronic disease.' The maximum concentration seen in the present study was only $307 \mathrm{IU} / \mathrm{ml}$, however, whereas Geha et al $^{1}$ reported values up to $9500 \mathrm{IU} / \mathrm{ml}$. Differences in patient management and treatment as a factor in modifying the IgE response cannot be excluded.

In the present study raised serum IgE concentrations seen in many infections with or without graft versus host disease. A number of infections have been reported to be associated with raised serum IgE. $^{4-6}$ In one study ${ }^{7}$ various respiratory viral infections were associated with higher IgE values in the acute compared with the convalescent phase of infection. This was interpreted as resulting from viral suppression of the IgE response. No preinfection values were quoted, however, and these results could equally well represent an acute IgE response to the viral infection, similar to the pattern seen in the figure. Other workers ${ }^{8}$ found an increase in $\mathrm{IgE}$ in the acute phase of cytomegalovirus and EpsteinBarr virus mononucleosis compared with preinfection values.

An interesting finding in our study was the invariant rise of serum $\operatorname{IgE}$ concentrations in patients with viral infections. T lymphopaenia or a disturbed $T$ cell subset ratio has been reported in viral infections..$^{10-12} \mathrm{~A}$ similar pattern of raised serum IgE concentrations and $\mathrm{T}$ lymphopenia has been shown in children with asthma ${ }^{13}$ and atopic eczema. ${ }^{14}$ The raised IgE concentrations found in acute graft versus host disease might also be associated with $\mathrm{T}$ lymphocyte imbalance, but occult viral or other infections, exacerbating or initiating acute graft versus host disease, cannot be excluded.

In conclusion, the use of raised serum IgE concentration as an early indicator of acute graft versus host disease has been precluded by the finding of raised values in a large number of infective episodes.

We thank members of the Westminster bone marrow transplant team for helpful discussion and access to clinical notes and to Mrs A Willett for preparation of this paper. We also thank Professor
H Stern, St George's Hospital Medical School, for assistance with virological investigations.

\section{References}

' Watson JG. Problems of infection after bone marrow transplantation. J Clin Pathol 1983;36:683-92.

${ }^{2}$ Geha RS, Rappaport JM, Twarog FJ, Parkman R, Rosen FS. Increased serum immunoglobulin $E$ levels following allogeneic bone marrow transplantation. J Allergy Clin Immunol 1980;66:78-81.

${ }^{3}$ Ringdén O, Persson U, Johansson G, et al. Correlation between increase in serum IgE levels and clinical signs of acute graft versus host disease. Exp Haematol 1982;10:suppl 10:94-5.

4 Nordbring F, Gunnar S, Johansson O, Espmark A. Raised serum levels of IgE in infectious mononucleosis. Scand J Infect Dis 1972;4:119-24.

${ }^{5}$ Mathur S, Goust J-M, Horger EO, Fudenberg HH. Immunoglobulin $\mathrm{E}$ anti-candida antibodies and candidiasis. Infect Immun 1977;18:257-9.

${ }^{6}$ Cox RA, Baker BS, Stevens DA. Specificity of immunoglobulin $\mathrm{E}$ in coccidioidomycosis and correlation with disease involvement. Infect Immun 1982;37:609-16.

' Perelmütter L, Phipps P, Potvin L. Viral infections and IgE levels. Ann Allergy 1978;41:158-9.

${ }^{8}$ Bahna SL, Horowitz CA, Fiala M, et al. Changes in serum IgE and IgM levels in heterophil-antibody positive infectious mononucleosis. Pediatr Res 1977;11:484-5.

' Bahna SL, Horowitz CA, Heiner CD. IgE in cytomegalovirus mononucleosis. American Academy of Allergy Meeting, Phoenix, Arizona 1978; Abstract 160.

${ }^{10}$ Wybran J, Fudenberg HH. Thymus-derived rosette-forming cells in various human disease states: Cancer, lymphoma, bacterial and viral infections and other diseases. J Clin Invest 1973;52:1026-32.

" Carney WP, Iacoviello V, Hirsch S. Functional properties of T lymphocytes and their subsets in cytomegalovirus mononucleosis. J Immunol 1983; 130:390-3.

12 Budillon G, Scala G, Onofrio CD, Cassaro S, De Ritis F. Diminished active $T$ rosette levels and increased spontaneous B lymphocyte blastogenesis in hepatitis B virus positive chronic hepatitis. Clin Exp Immunol 1983;52:472-6.

${ }^{13}$ Byrom NA, Caballero F, Campbell M-A, et al. T cell depletion and in vitro thymosin inducibility in asthmatic children. Clin Exp Immunol 1978;31:490-8.

${ }^{14}$ Byrom NA, Staughton RCD, Campbell M-A, et al. Thymosininducible 'null' cells in atopic eczema. $\mathrm{Br} J$ Dermatol 1979;100:499-509.

Requests for reprints to: Miss SA Walker, Protein Reference Unit, Department of Chemical Pathology, Westminster Hospital, 17 Page Street, London SW1P 2AR, England. 